\title{
A technique for the measurement of aggressive behavior in mice
}

\author{
STEFANO PUGLISI-ALLEGRA and PAOLO RENZI \\ Laboratorio di Psicobiologia e Psicofarmacologia, C.N.R., Via Reno, 1-00198 Rome, Italy \\ and Institute of Psychology, Facoltà di Magistero, University of Rome, Rome, Italy
}

\begin{abstract}
This paper describes an apparatus permitting the study of aggressive behavior in mice. Aggressive behavior may be spontaneous or induced by means of an electric shock delivered through the tail.
\end{abstract}

Automated techniques for the study of pain-induced aggressive behavior in monkeys (Azrin, Hutchinson, \& Sallery, 1964) and rats (Berg \& Baenninger, 1972) have been described. This report describes a simple device to record and quantify the bites between pairs of mice experiencing painful stimulation.

Two mice are placed in an experimental chamber $(9 \times 9 \times 14 \mathrm{~cm})$ with walls and grid floor of gray Plexiglas. Two holes $(1 \mathrm{~cm}$ diam, $1 \mathrm{~cm}$ above the grid floor) allow the tails to extend out of the chamber on two opposite walls. A threaded bushing glued to each tail by means of Bostik 800 is fixed by a nut in the center of a ball bearing so that the mouse can move freely with no danger to the tail (Figure 1). In pilot experiments in which ball bearings were not used, tail twisting produced immobility reactions in the

We gratefully acknowledge the electronic design of M. Flamini and the technical assistance of L. Fabiani. mice. The bushing stays in place for 10 days with no damage to the tail. The distance between the ball bearings and the walls of the chamber is adjusted (according to the size of the mice) by screws allowing the ball-bearing supports to move forward and backward. The two ball bearings work as slip rings for a contact detector (Figure 1). Low current ( 2 microA) passes through both mice during biting and is amplified by the contact detector so that all bites, but no other physical contacts, are recorded by a digital counter. Selective discrimination of bites from other body contacts is obtained through a trigger control (Figure 2).

Aggressive behavior is induced by shocking both mice simultaneously. The electric shock $(.2 \mathrm{~mA})$ is delivered via two electrodes to the part of the tail between the hole and the ball bearing (Figure 1). After several intensity values were tested, $.2 \mathrm{~mA}$ was found to be the optimal intensity for the production of

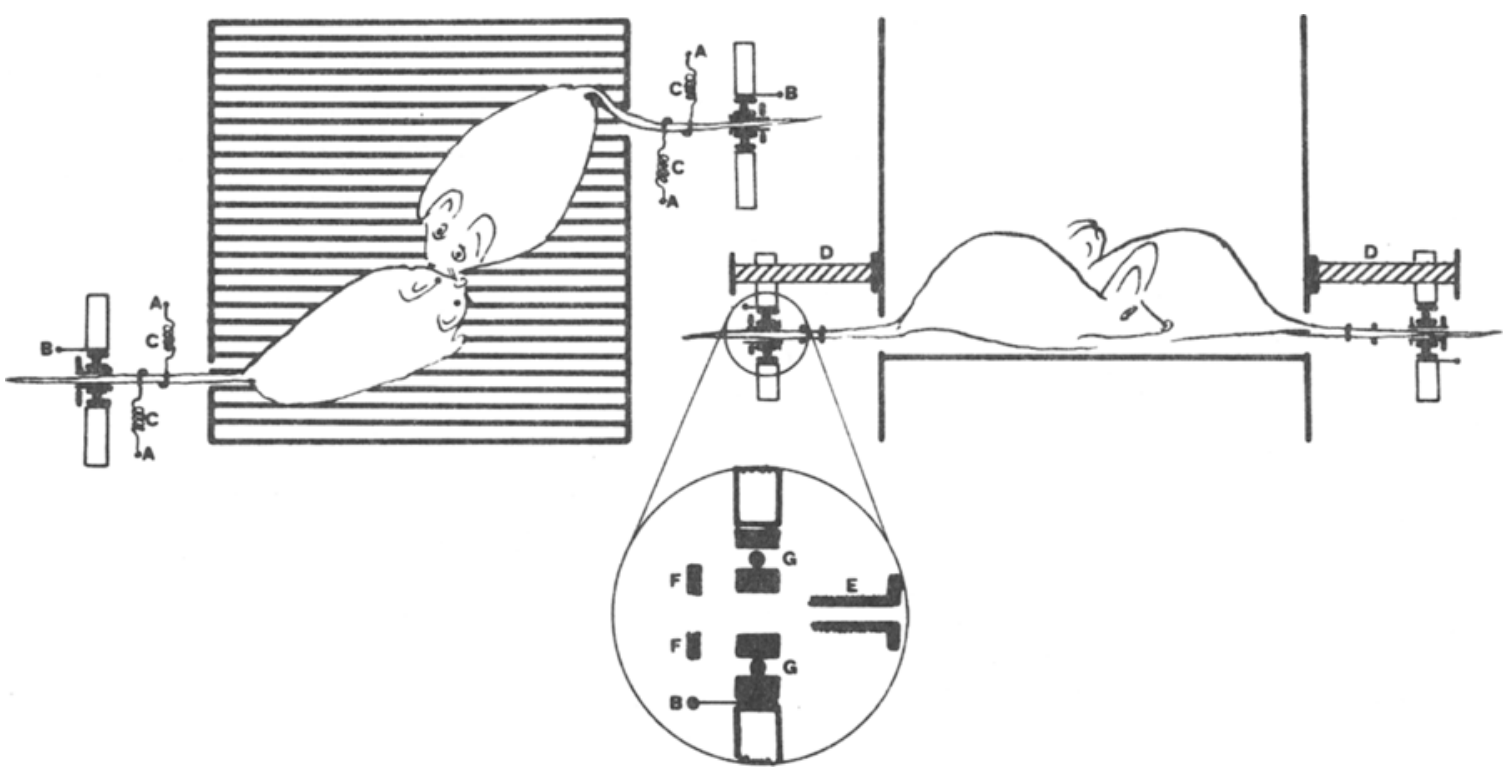

Figure 1. (A) Shock connections. (B) Sensor connection. (C) Springs. (D) Screws for the adjustment of subject position. (E) Bushing. (F) Nut. (G) Ball bearing. 

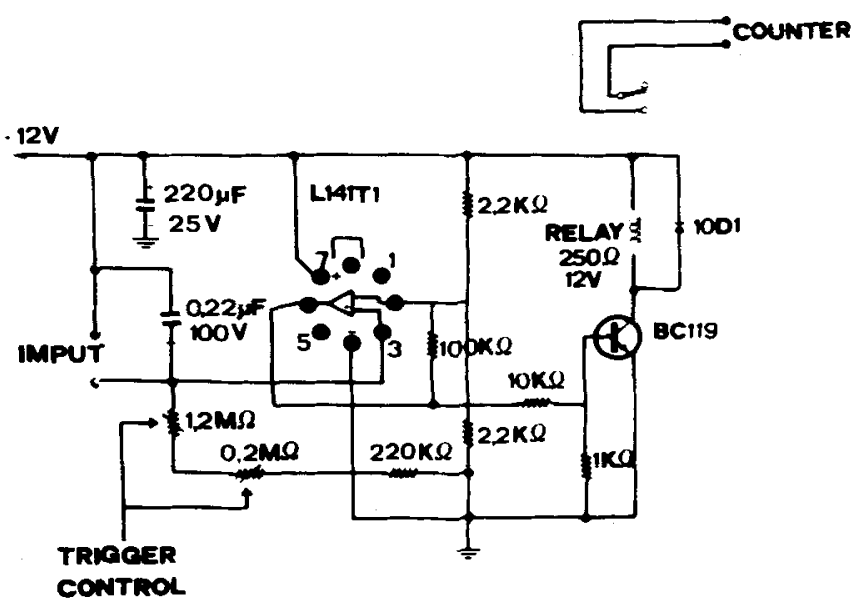

Figure 2. L141T1 = SGS high-performance operational amplifier.

shock-induced aggression. Values higher than $.2 \mathrm{~mA}$ caused excessive arousal in animals without affecting the amount of biting. Values lower than $.2 \mathrm{~mA}$ often produced habituation. The number of bites can be recorded during shock stimulation, since the electric

\section{Table 1}

Mean Number of Bites with Administrations of Saline, Arecoline, and Apomorphine for Different Groups of Mice

\begin{tabular}{cccccc}
\hline & \multicolumn{2}{c}{ Arecoline } & & \multicolumn{2}{c}{ Apomorphine } \\
\cline { 2 - 3 } \cline { 5 - 6 } Saline & $.25 \mathrm{mg} / \mathrm{kg}$ & $.5 \mathrm{mg} / \mathrm{kg}$ & $.5 \mathrm{mg} / \mathrm{kg}$ & $1 \mathrm{mg} / \mathrm{kg}$ \\
\hline .00 & 16.22 & 43.77 & 3.66 & 8.77 \\
\hline
\end{tabular}

Note-There were three pairs of animals per group. shocks are produced by two independent sources.

This technique may be improved by spraying a hydrorepellent substance $\left(\mathrm{MoS}_{2}\right)$ on the grif floor in order 10 prevent films of urine. and by spreading an EEG-type electrical coupling cream on the contact tail bushing.

This technique has been tested with inbred mice of the $\mathrm{C} 57 \mathrm{Bl} / 6 \mathrm{~J}$ strain. which is not spontaneously aggressive. The effects of a cholinergic stimulant (arecoline) and of a dopaminergic agent (apomorphine) were assessed on shock-induced aggressive behavior. Aggressive behavior was elicited by both drugs, as shown in Table 1.

Statistical analyses showed significant differences between the saline group and the groups injected with lower doses of both drugs. Significant differences were also found between groups injected with the two doses of each drug $(p<.01)$.

\section{REFERENCES}

M/RIS. N. H., HITCHINSON. R.. A SALLERY, R. D. Measurement of aggression toward inanimate object. foumed of Experimental Analisis of Behavior. 1964. 7. $223-23 x$.

Berg, D. S., A BaEnninger, $R$, A device for recording angressive contact between animals. Behavior Research betheds \& Instrumemation. 1972. 4. 39.

(Received tor publication August 6. 1976: revision accepted August 9. 1977.) 